\title{
Nigeria's Developmental Challenge: Conceptualising Law and Development in the Nigerian Context
}

\author{
Somadina Ibe-0jiludu \\ Faculty of Law, Godfrey Okoye University, Enugu, Nigeria \\ Email: somadina.ibe-ojiludu@city.ac.uk
}

How to cite this paper: Ibe-Ojiludu, S. (2022). Nigeria's Developmental Challenge: Conceptualising Law and Development in the Nigerian Context. Beijing Law Review, 13, 1-22.

https://doi.org/10.4236/blr.2022.131001

Received: December 14, 2021

Accepted: February 21, 2022

Published: February 24, 2022

Copyright $\odot 2022$ by author(s) and Scientific Research Publishing Inc. This work is licensed under the Creative Commons Attribution International License (CC BY 4.0).

http://creativecommons.org/licenses/by/4.0/ (c) (i) Open Access

\begin{abstract}
Law and Development is not practised or founded in a vacuum. It has a milieu, a theoretical foundation upon which it is tethered. In the field of Law and Development, there are some assumed theoretical bases or discourses which have had some enduring influence on the way the field has evolved, is viewed or is practised. This article looked at Nigeria's developmental challenges from the lenses of some of these theoretical assumptions and equally looked at some of the assumptions from the Nigerian context. The article argued that Nigeria is non-developed partly because the understanding of development by development scholars in the country and the structure of Nigeria's legal arrangement do not accord with some key extant theoretical frameworks in Law and Development. Examples of such theoretical frameworks include the institutionalist legislative theory, prescription of roles for role occupants, problem-solving methodology of the pragmatic school of philosophy, the problem of drafting law that relies on entropic practices or the trial-and-error procedure and the scope of "law" in Law and Development movement. With regard to the scope of law in Law and Development movement, the article argued for the accommodation of customary law as law and thus reflected on its possible developmental impact. The article made a case for the harnessing of the potentials of law for the facilitation of development in Nigeria, guided by the theoretical assumptions in Law and Development. The article utilised the doctrinal research methodology.
\end{abstract}

\section{Keywords}

Law and Development, Seidman, Nigeria, Development, Sustainable Development 


\section{Introduction}

Many policy makers, lawyers and legal scholars are not familiar with Law and Development as a new area of inquiry (Lee, 2017). Law and Development and its theoretical frameworks are new and still evolving, thus, the affirmation that doctrine of Law and Development "is not static" (Malinovsky \& Dobrotvorsky, 2021). Searching for new theories in the field "is continuing" (Malinovsky \& Dobrotvorsky, 2021). This article argues that Nigeria is non-developed partly because the understanding of development by development scholars in the country and the structure of Nigeria's legal arrangement do not accord with some key extant theoretical frameworks in Law and Development.

This article is important because it aims to arouse interest in the study of the intersection between Law and Development among development/legal experts in Nigeria. This arousal is necessary because in Nigeria, Law and Development is not a discipline in any law faculty. It is thus not surprising that the field is not captured in the National University Commission's Benchmark Minimum Academic Standards (BMAS). ${ }^{1}$ The implication of the above is that in Nigeria, lawyers are trained who are remote from the problems of the masses which essentially border on issues of development. Most existential problems of individuals revolve around lack of improvement ${ }^{2}$ in any of the facets of development: economic development, socio-political development and human development. ${ }^{3}$ The additional implication of this absence of Law and Development discourse in the training of Nigerian lawyers is that law appears reduced to a mere money-making venture of lawyers who care less about the overall welfare of the masses.

The central question of this article is: Is Law and Development correctly conceived in the Nigerian context? Relying on some existing theoretical platforms in the field, the article answers the question by addressing the following sub-questions: Is the conception of development in Nigeria restricted to only economic development or is it multi-dimensional? Does the customary law in Nigeria have a strong recognition vis-à-vis the formal law in such a way that the former can play a role in Nigeria's development, unfettered by the latter? Why does formal law fail in Nigeria? To which extent is law itself conceived as part of development in Nigeria as envisaged by the third moment in Law and Development?

In his most widely received and influential work in the field of development, Dudley Seers (1969) shows that one of the important issues in development dis-

\footnotetext{
${ }^{1}$ BMAS refers to a document from Nigeria's university regulatory body, National University Commission, which prescribes the minimum academic content and expected outcomes of undergraduate and post-graduate courses in universities in Nigeria.

${ }^{2}$ Development refers to improvement in individual's living conditions (Ibe-Ojiludu, 2018: p. 131). Indeed, "if there is no attention to the quality of growth and to social change one cannot speak of development" (Brandt and Other Members of an Independent Commission, 1986: p. 48).

"'Development" is popularly conceived as an event expressed in these three interrelated components: human development, economic development and socio-political development (see, for instance, the following: Twinning, 2009: p. 323; Ibe-Ojiludu, 2018: p. 131 and Baderin, 2010: pp. 22-28).
} 
course is the determination of the [theoretical] yardstick for assessing if development has taken place. Spheres of activities are carried out on the basis of theoretical convictions. One of the jobs of scholars is to unravel the underlying understanding (theory) behind activities and/or to propose one.

Law and Development emphasises the conscious deployment of law to effect development (see the following: Ocran, 1978; Baderin, 2010 \& Newton, 2006). Such a conscious deployment is not practised or founded in a vacuum. Law and Development has a milieu, a theoretical foundation upon which it is tethered. In the field of Law and Development, there are some assumed theoretical bases or discourses which have had some enduring influence on the way the field has evolved, is viewed or is practised. This article looked at Nigeria's developmental challenges from the lenses of some of these theoretical assumptions and equally looked at some of the assumptions from the Nigerian context.

This introduction is followed by Section 2 which discusses the concept of development as understood in development plans and practice in Nigeria. Section 3 reflects on the scope of law in the Law and Development movement, dwelling on the status of customary law in Nigeria. Section 4 considers why law fails in Nigeria. This is followed by Section 5 which reflects on the absence of law factor in literature on development in Nigerian and the incompatibility of the absence with the third moment in Law and Development. There is then the concluding Section 6 which summarises the findings of the article.

\section{The Concept of Development in Development Plans and Practice in Nigeria}

At the beginning of this century, the World Bank published Can Africa Claim the 21st Century? A reading of the publication shows an understanding of "development" that appears sometimes tilted in favour of economic development. For instance, the document opines that many of the world's problems of development are "largely confined to Africa" (International Bank for Reconstruction/World Bank, 2000: para. 1). Such an assertion is correct if "development" is viewed only from the lenses of the economy. In terms of certain aspects of socio-political development, Africa does not appear to lag behind the Asian region. Africa, for example, has a human rights system that is much more extensive than Asia's. It has been asserted that Asia, unlike Europe, America and Africa, remains the only region of the world that does not have a region-wide-based human rights-protection mechanism (Raportoru, 2016: pp. 23-24). Based on this, it would not be correct to say that development problems are "largely confined to Africa" if one focuses on certain aspects of socio-political development. But if development is viewed from a mind-set that confines development to only economic development, it would then not be out of place to say that the world's problems of development are "largely confined to Africa". W. Brandt and other members of an independent commission on issues in international development once affirmed that "one must avoid the persistent confusion of [economic] 
growth with development" (Brandt et al., 1986: p. 23). The International Labour Organisation also shared this affirmation (Szirmai, 2005: p. 7).

The above confinement of "development" to only economic development is diffused in the development plans and practice of development in Nigeria. For instance, most of the development plans and rolling plans initiated by Nigeria since her independence mostly revolves around only economic development (see for instance, Ibietan and Ekhousuchi, 2013: pp. 299-307). Also, many writers on development in Nigeria mostly confine themselves to the aspects of development that are "economic". For example, Brian-Vincent Ikejiaku (2009: p. 31, 36-37) speaks about two strands of development, political and economic development which led him to offer a definition of development which he believes is appropriate to the present level of development in Africa and which satisfies the populace's economic and political benefits: “development as an increase in economic growth, properly harnessed by leaders toward both economic and political enhancement of the citizens". One problem with this definition is that in as much as it accommodates both economic and political development (thus not caught in the traditional bias which restricted development to only economic development), it still appears glued to the mind-set that views development only from the economic lens. That is why the starting point of the definition is still with "the economic", "economic growth", to be specific. The definition supposes that it is only when economic growth has taken place that such a growth would be properly harnessed for the citizens' economic and political enhancement.

Conceiving development only in economic terms in Nigeria falls short of modern conceptualisation of development. Dudley Seers, for instance, once affirmed that "we have all been aware that development consists of much else besides economic growth" and that it is careless confusing development with economic development or even economic development with economic growth (Seers, 1969: pp. 1-2). Seer is correct. This is because if we agree that development entails, as conceived by UNGA (1997: para. 1), securing for the people a higher qualitative life, then development is equally locatable in non-economic spheres since people can experience higher qualitative life in their socio-political and human conditions. Thus, there appears to be a consensus in scholarship and in the practice of states in international law (as typified in the UNGA's Agenda for Development) that development accommodates, not only economic development (see, for instance, the following: Brandt et al., 1986: p. 123; Ibe-Ojiludu, 2018: pp. 130-134; Ikejiaku, 2009: pp. 36-37), but also matters bordering on improvement in the human and socio-political conditions of the human person (Ibe-Ojiludu, 2018: p. 131; Baderin, 2010: pp. 22-28; Twinning, 2009: p. 323). Development is "multi-dimensional" (UNGA, 1997: para. 1). Economic, human and socio-political development constitute what Mashood Baderin (2010: p. 28) once likened to Africa's "proverbial three-legged stool".

I would however point out that even if development is correctly conceived in Nigeria-that is, in its economic, socio-political and human dimensions and ef- 
fort sincerely made by the government to effect development, the structures of international law can sometimes militate against development in Nigeria. Mick Moore (2001: pp. 132 \& 134) believes that underdevelopment in Africa (of which Nigeria is part of) was shaped and continues to be shaped to a large extent by the interaction between countries in the global north who are rich and those of the global south. He reasons that "bad governance" is not inherent in the culture or traditions of the poor countries of the global south nor is it a product of poverty. He affirms that bad governance in the global south is borne from the ways in which state authority in the south has been constructed "-and is being maintained-" through political and economic interactions with other parts of the world. In summary, Moore (2001: p. 387) is saying that the countries of the South are negatively different from those of the North because the states of the south appeared in an international environment which was already dominated by the relatively powerful and rich countries of the North. These countries of the North have indirectly and directly created and create, controlled and control, and shaped and still shape the states of the global South (Moore, 2001: p. 387).

The control and shaping of states of the global south are, for instance, reflected in the scheme of the World Trade Organization (WTO). The mission of WTO is the removal of barriers to trade between countries. This entails the globalization of world trade. Unfortunately, WTO is quick to protect the interest of the global north more than that of the global south. It protects the interest of many of the multinational pharmaceutical corporations of the north by its regime of Trade-Related Aspects of intellectual property Rights (TRIP). Agreements on TRIPs protect patents, copyrights etc. for up to 20 years. This creates a monopoly for these corporations. Thus, countries of the global south are precluded from producing essential medicines that would be of help in their fight against some diseases. As succinctly put elsewhere, the monopoly keeps "the prices of medicines expensive such that majority of people... in... Developing countries are unable to afford them" (Odhiambo, 2007).

Also, whenever the colonising powers of Europe conquered territories they and the international law then in vogue dubbed such entities "uncivilised". They were then declared terra nullius and by this, international law was legitimising "conquest as legal" (Anghie, 2007: p. 745). Contradictorily, the same powers and international law would in other cases accord some recognition to treaties such powers entered into with the "uncivilised" (Anghie, 2007: p. 745).

However, it is important to point out that the above-highlighted militating factor [from Moore] against the development of the countries of the global south cannot be a reason that Nigeria and other African countries would easily invoke as responsible for their inability to join the rank of developed countries. This is because some countries of the global South-like the so-called Asian Tigers-surmounted to an extent their underdevelopment challenge unlike some other countries, majority of whom are in Africa. These sets of countries (the Asian Tigers) experienced and still experience the incapacitating interaction 
between the North and the South that Moore spoke about. But they were and are undeterred as reflected in their flowering economic and human development.

It is important to properly conceive development in Nigeria. When development is properly conceived, actors in the field would know their developmental goals and then properly work to achieve those goals. Thus, they would deploy the necessary intellectual and practical resources geared towards the realisation of the targeted developmental goals. Properly conceiving development would equally place them in a position to know when development has taken place. Development is a conscious effort. Thus, Tawia Modibo Ocran (1978: p. 17) one of the foremost early scholars on Law and Development in the African context, would reason that "Law and Development" is a study of the conscious uses of the normative system called "Law" to help bring about economic development'. "Conscious" is "the key word here"; although law's role in development is obvious enough, the absence of its conscious deployment "has undermined its possible instrumentality in the developmental process of most African States" (Baderin, 2010: p. 4).

Since one can affirm from the above that Law and Development entails the conscious use of law to effect development, it is important to understand the boundaries of "law" in Law and Development. The next section will explore the scope of "law" in the Law and Development Movement and how customary law is crucial in Law and Development especially within the Nigerian context.

\section{The Scope of "Law" in the Law and Development Movement: The Customary Law}

Social control, among other facets, refers to "every way through which the human society exercises a modifying influence upon itself or part of itself" (1941, p. $22)^{4}$. The control can be legal or non-legal, two components that are interdependent (Stone, 1966: pp. 247-250). Development falls within the non-legal component since it is not stricto sensu a legal phenomenon.

However, since law is conceived as an instrument of social control (Stone, 1966: pp. 741-797; Ibe-Ojiludu, 2018: p. 138; Twinning, 2009: pp. 333-334), it is capable of evolving development. This is a departure from the traditionally popular understanding of law as playing an order and security role. "Law has a developmental role" (Ibe-Ojiludu, 2019: p. 46).

In the Law and Development enterprise, all the dimensions of law count: legislations/statutory laws, the common law, the customary law and the international law (see, for instance, Ibe-Ojiludu, 2018: pp. 134-138). Thus, law and development is not restricted to what has been described as the "Westphalian Duo" (Twinning, 2009: p. 357): "municipal state law and public international law" (Twinning, 2009: p. 357). Consequently, customary law is equally crucial in the mission of Law and Development.

One of the major challenges that Law and Development movement faces in ${ }^{4}$ Cairns, 1941: p. 22, as quoted in Stone, 1966: p. 741. 
Nigeria is a weakened legal framework for customary law. This prevents customary law from playing some developmental role.

Customary law is constitutionally recognised in Nigeria (see Constitution of the Federal Republic of Nigeria 1999, s. 315). It is defined as "any system of law not being the common law and not being a law enacted by any competent legislature" (Zaidan V Mohssen, 1973). It is the "organic or living law" deployed by the indigenous people for regulating their life and activities; it is referred to as "organic" because it is non-static (Oyewunmi v Ogunesan, 1990). Other features of customary law include being "unwritten" (Alfa V Arepo, 1963) or "unrecorded" (Aku v Aneku, 1991).

Customary law in Nigeria can have some developmental impact. With regard to land ownership, for instance, customary law can enhance human development by a regime that guarantees equal access to land for both the rich and the poor. This is because in the customary law, individual land ownership was unknown but rather communal ownership (see for instance, Amodu Tijani v Secretary Southern Nigeria, 1921) ${ }^{5}$. Unfortunately, this was ruptured by the advent of colonialism which imported and imposed a legal regime that displaced this customary law practice (see, for instance, Brimah Balogun and Scottish Nigeria Mortgage v Saka Chief Oshodi, 1933) ${ }^{6}$. A restoration of the land tenure system in its pre-colonial purity can go a long way in the area of enhancing the human development of Nigerians. This is because access to land plays a role in ensuring access to good personal income. ${ }^{7}$ Personal income is important for the realisation of human development. ${ }^{8}$ With a good personal income, access to education, health care and other aspects of human development that guarantee a decent standard of living is assured. This is because the two faceted components of an adequate standard of living entail "the expenditure necessary to buy a minimum standard of nutrition and other basic necessities and a further amount that varies from country to country, reflecting the cost of participating in the everyday life of society" (World Bank, 1990: p. 26).

Also, the impact of customary law to development can be seen in the area of customary law arbitration. Customary law arbitration is recognised in Nigeria (see, for instance, Eke v Okwaranyia, 2001; Ohiaeri v Akabeze, 1992; Agu v Ikewibe, 1991). It has been defined as "referring a dispute to the family head or ${ }^{5}$ In this case, the court affirmed that "the notion of individual land ownership is quite foreign to native ideas".

${ }^{6}$ In Brimah Balogun and Scottish Nigeria Mortgage and Trust Co. v. Saka Chief Oshodi, 1933 where the colonial court rather accommodated individual land ownership of the English land tenure system by reasoning that "no party shall be entitled to claim the benefit of any local law or custom if it shall appear either from the express contract or from the nature of the transaction that he agreed that his obligations should be regulated exclusively by English law".

${ }^{7}$ For a study on the capacity of a favorable land tenure system to economically empower a hitherto disadvantaged group, see Hallward-Driemeier and Hasan, 2013: pp. 19-36 where the authors show how strengthening of land rights of women (as can be seen in the experience of the women of Akwapim in Ghana) can be economically rewarding to them.

${ }^{8}$ One of the three indices of the UNDP's Human Development Index (HDI) is personal income. HDI is a geometrical mean of health, education and personal income (see, for instance, Larrocal, Arevalo-Serrano, Duran Vilal et al., 2017: p. 2. 
an elder of the community for a compromise solution based upon subsequent acceptance by both parties of the suggested award, which becomes binding only after such signification of its acceptance and from which either party is free to resile at any stage of the proceedings up to that point." (Agu V Ikewibe, 1991). Thus, the decision or the award must be accepted at the time it was made (Eke $V$ Okwaranyia, 2001).

Commercial cases span for many years in law courts in Nigeria. This discourages investment (especially foreign direct investment) because an investor would be unwilling to invest in a system that would trap his investment should a dispute occur. Arbitration is less expensive than litigation. It uses a process that is much more flexible than that obtainable in a law court. Thus, it is faster than litigation in resolving commercial disputes. Investors are quick to invest in a legal terrain that promotes an efficient arbitration culture.

Foreign direct investment contributes to development. It has been argued that although foreign direct investment can have some harmful environmental consequences, an analysis of samples from 44 African countries regarding their scores on Sustainable Development Goals (SDGs) shows that foreign direct investment can have some positive influence on SDGs scores (see, for instance, Aust et al., 2019) ${ }^{9}$. Customary law arbitration, therefore, can have some developmental impact to the extent that it promotes investment, especially foreign direct investment. Thus, the assertion by Seidman many years ago that "customary law cannot lead to development" (Seidman, 1972: p. 315) is not correct.

Unfortunately, customary law arbitration is impaired in Nigeria. This is because customary law upon which it is based has a weak standing in the hierarch of laws in Nigeria. In Nigeria, the customary law is inferior to the formal system of law. For instance, in the Evidence Act (2011), a customary law is considered a valid law only if it is judicially noticed and passes the repugnancy test (which obliges that customary law must conform to natural justice, equity and good conscience) and non-opposed to public policy. Discriminatorily, the formal law system (like statutes from the legislature and case law) is not subjected to repugnancy test and public policy requirement. In addition, it is through the formal system that the customary law is subjected to the repugnancy test. Also, customary law is not acceptable as a valid law if it is inconsistent with a statutory provision (see Mojekwu v Mojekwu, 1997; Nwachukwu v Nnoremele, 1957).

It is therefore recommended that customary law should be accorded a recognition that is equal to and not subservient to the laws of the formal system. This will allow the developmental potentials of the customary law to blossom unhindered by legislative enactments and case law. It is also recommended that the only legal authority that should be above the customary law in Nigeria is the $\mathrm{Ni}$ gerian constitution which by virtue its supremacy clause is supreme over all laws ${ }^{9}$ Here, the authors argue that although foreign direct investment can have some harmful environ-mental consequences, an analysis of samples from 44 African countries regarding their scores on Sustainable Development Goals (SDGs) shows that foreign direct investment has some positive influence on SDGs scores. 
which include legislative enactments and case law.

\section{The Limit of Law: Why Laws Fail in Nigeria.}

Many laws promulgated in many African countries after attaining independence have failed to transform old institutions and as a result promises that are not kept, bad governance and poverty are the order of the day, thus the people have lost "the fatal race" (Seidman \& Seidman, 2007: p. 22). This has led many to believe that law is not capable of changing behaviour. Seidman and Seidman refuted this belief by citing some cases where law is a "but for" cause of changed social behaviour. The authors asked, "Would anyone pay a tax, but for the law? Would anyone vote, but for the law?" (Seidman \& Seidman, 2007: p. 22). The above-highlighted failure of law to transform old institutions also plagues Nigeria (see, for instance, Ibe-Ojiludu, 2018). This failure can be attributed to the factors enumerated and discussed below.

\subsection{Ignoring the Institutionalist Legislative Theory}

The institutionalist legislative theory, which draws from sociology of law, legal realism and problem-solving, revolves around the potential of utilising law as the primary tool of government for solving social problems (Seidman \& Seidman, 2007: p 29). Legal realism reminds us of the deep-seated reality that law-in-action does not appear the same as that which is prescribed in the law-in-the-book (Seidman \& Seidman, 2007: p. 29). The work of the drafters is to reduce the gap that exists between what the law says and what people in fact do and this entails the drafter asking, "why do people behave as they do in the face of a rule of law?" (Seidman \& Seidman, 2007: p. 29). The drafter answers this by appealing to the sociology of law and the problem-solving methodology of the pragmatic school of philosophy.

\subsubsection{Sociology of Law's Prescription of Role for Role Occupants}

Law usually prescribes a specific role to people who are called "role occupants" (Seidman \& Seidman, 2007: p. 29). Two classes of role occupants are usually targeted by a law: the primary role occupants who are social actors in the civil society and the secondary role occupants which refer to the agencies that the law obliges to implement the content of law with the objective of inducing the primary role occupants to act according to the law's prescription (Seidman \& Seidman, 2007: pp. 29-30). Social problems cannot be resolved if the secondary role occupants are incapacitated and the primary role occupant usually considers the likely behaviour of an implementing agency (in addition to the law itself and the objective and subjective non-legal factors that "comprise the particular country and location-specific circumstances") before deciding on whether to act in conformity with a given law (Seidman \& Seidman, 2007: p. 30).

The above analysis of Seidman and Seidman is in order if we consider, for example, the failure of Nigeria's Economic and Financial Crimes Commission (EFCC) to tame corruption in Nigeria. It has been reasoned that when the EFCC 
is not well funded to carry out its statutory mandate, "this is an invitation to people to freely engage in corruption" because the commission cannot "bite" (Ibe-Ojiludu, 2018: p. 147). Besides, with the openness of the EFCC to "political manipulation and lack of deterrence arising from its regime of plea bargaining" there is the likelihood that citizens would not conform to the goals of the Act establishing the commission because of the belief that "after all the implementation of its provisions is subject to political negotiations and bargaining" (Ibe-Ojiludu, 2018: p. 147).

\subsubsection{Problem-Solving Methodology of the Pragmatic School of Philosophy}

With regard to the problem-solving methodology of the pragmatic school of philosophy, the legislative theory offers a four-step guide to lawmakers to aid their fact-gathering process:

1) Describe the social problem, including the behaviours that comprise it, which the proposed law aims to resolve; 2) identify the causes of those problematic behaviours; 3 ) show that logically the bill's detailed provisions will likely overcome those causes and induce new, more appropriate behaviours; and 4) incorporate in the bill a monitoring and evaluation process by which, after the law's enactment, those affected-especially the poor and vulnerable-can provide additional evidence as to the new law's social impact, laying a basis if necessary for improving it (Seidman \& Seidman, 2007: pp. 33, 45).

Seidman and Seidman are of the position that the likelihood that the provisions of a proposed bill will solve a particular social problem must be demonstrated by "an adequate description of relevant evidence at each of these four steps". It is for this reason that Seidman and Seidman recommend that every important bill should be accompanied by a research report which tracks the above-enumerated four steps containing some reason which is informed by experience and which is capable of persuading a "rational sceptic" that the proposed bill will transform institutions and solve targeted problem.

The above problem-solving steps show that the work of drafting a bill is not merely a legal issue. An adequate description of the problem and solution inevitably demands looking for expert advice and advice from those who have the requisite experience on relevant extra-legal issues. This brings out the interdisciplinary nature of using legislature to bring about development.

Recently, the Nigeria's National Assembly passed the Company and Allied Matters Act 2020. The Act has generated condemnation from many practising lawyers, lawyers in the academia, journalists and many civil society organisations because of certain provisions in its Part F which restrict the social space. For instance, section 834 of the Act empowers the Corporate Affairs Commission to suspend the trustees of a Non-Governmental Organisation (NGO) and appoint interim manager(s) to oversee the affairs of the organisation where "it reasonably believes" that "it is necessary or desirable for the purpose of...public interest", among other reasons (Company and Allied Matters Act 2020, s. 834). 
This public-interest provision was not in the old and now repealed Companies and Allied Matters Act 1990. What is "public interest" is vague and amenable to parochial interpretation by the membership of the Corporate Affairs Commission, a commission populated by political appointees. Thus, the "public interest" provision may be invoked against civil society organisations which criticise any of the Federal or State governments in Nigeria. Company and Allied Matters Act 2020, which was passed during the restriction and lock-down arising from the COVID 19 pandemic, was greeted with much condemnation because there was no public hearing prior to its promulgation which would have helped in trashing out some grey areas of the Act with input from affected entities and those conversant with the extra-legal issues in part $\mathrm{F}$. This is a violation of the interdisciplinary demand of the above-highlighted four-step guide to lawmakers geared towards their fact-gathering process.

\subsection{Drafting Law That Relies on Entropic Practises or the Trial-and-Error Procedure}

Seidman and Seidman acknowledge that law too often fails to change behaviour. However, with regard to legislative law, the failure, according to them, is because legislative drafters adopt any of what they call "entropic practises" or trial-and-error method.

\subsubsection{Entropic Practices}

Entropic practices fall into four categories. In the first category of entropic practices, public interest is undermined. The influence of special interest group(s) is dominant or accentuated (Seidman \& Seidman, 2007: p. 26). This is exemplified in Nigeria in a recent law passed by the Lagos State House of Assembly. According to the law, "The collecting Banks shall provide the statement of accounts for all Land Use Charge payments to the Accountant-General of the State. Alpha Beta or any other designated person(s) or corporate body who has the responsibility of monitoring the incoming revenue of the State through the collecting banks, shall provide a report to the Accountant-General of the State" (Land Use Charge Law, 2018). Alpha Beta is a private company allegedly owned by a former governor of Lagos State, Bola Ahmed Tinubu (Sahara Reporters, 2018). The above-cited provisions of the Lagos State's Land Use Charge Law 2018 essentially favour Alpha Beta. The firm is to be employed by Lagos State Government for the verification of payments (to the state funds) arising from the Law. When confronted by this anomaly, the Lagos State House of Assembly, through its spokesperson said, "It was a very costly mistake that should not have happened" (Ogundipe, 2020). This Lagos State Law is a classic example of a law created to serve some parochial interest instead of the common good.

The second category of entropic practices emphasises criminalising with heavy penalties unwanted acts inimical to development; this is contrary to experience which shows that a legal regime that institutionalise transparency and accountability can be much more effective in curbing anti-development attitudes 
(for example, corruption) than criminalisation (Seidman \& Seidman, 2007). The present Economic and Financial Crimes Commission (establishment etc.) Act 2004 (EFCC Act), a major anti-corruption Act in Nigeria, has not succeeded is reducing corruption in Nigeria. Nigeria ranks 146 out of 198 countries in the 2019 Corruption Perceptions Index, with an abysmal score of 26/100 which is a far cry from 87/100 garnered by a country like Denmark (Transparency International, 2020). The failure of the EFCC Act in combating corruption is a product of poor anti-corruption strategy birthed by the Act. Instead of evolving strategies that promote accountability and transparency, the Act emphasises investigating, arresting and prosecuting offenders. Such a regime that only criminalises corruption may not substantially deliver an absence of corruption in Nigeria. This is because it is generally expensive to prosecute a crime and a "poor state [like Nigeria] cannot afford the cost when the level of corruption in the state is systemic $^{10}$ (that is widespread)" (Ibe-Ojiludu, 2018: p. 154). And this is in addition to the fact that running Nigeria is expensive because of the multi-layered nature of her structure, among other factors. Nigeria has a federal government, 36 state governments and the governments of the Federal Capital Territory. This is in addition to her 776 local governments. There is thus the need for an amendment of the EFCC Act to usher in a regime that is tilted more in favour in institutionalising transparency and accountability and deemphasising the criminalisation of corruption.

In the third category of entropic practises, law drafters copy foreign laws which do not take into account country-specific circumstance and peculiarities-Bhutan for example copied a commercial law in US which has some sections on transactions that involve railroad even though the country "had no railroad within its boundaries" (Seidman \& Seidman, 2007: p. 26). Cases of legal transplants are not uncommon in Nigeria. The EFCC Act highlighted above is a product of a legal transplant (see Ibe-Ojiludu, 2018: p. 150) ${ }^{11}$. Some legislations in Nigeria (see, for instance, Interpretation Act, 2004) make applicable in the country Statutes of General Application (SOGA) effective in England on January 1st, 1900. These legislations make applicable in Nigeria statutes made in England with English people in mind. Thus, "an important group of statutes which have been accepted almost without question as applying in Nigeria are those relating to real property and conveyancing; ...the Wills Act, 1837, ...the Conveyancing Act, 1881, ...the Settled Land Act, 1882, ...the Common Law Procedure Act, 1852; ...Another group of statutes which have been held applicable to govern

${ }^{10}$ The Nigerian Vice President, Yemi Osibanjo, who is a Professor of Law and a Senior Advocate of Nigeria, once asserted in an official function, "The truth of the matter is that we all know that corruption in Nigeria is systemic" ("...Truth of the Matter is that Corruption is Systemic in Nigeria-Osibanjo", 2017).

${ }^{11}$ In this cited work, it is shown that the former Nigerian president, Olusegun Obasanjo, "fought" for the promulgation of the EFCC Act because of his belief that replicating in Nigeria a legislation similar to the anti-corruption laws in Singapore and Hong Kong would eradicate corruption from Nigeria; the EFCC Act is patterned after the anti-corruption laws of Hong Kong and Singapore, countries that are global examples of anti-corruption success. 
commercial dealings. They include the Statute of Frauds, ...the Infants Relief Act, 1874, ...the Mercantile Law Amendment Act, 1856" (Lawal V Younan, 1961). The Criminal Code in Nigeria is modelled closely on the 1899 State of Queensland (Australia) Code and the Nigerian Code itself would be adopted by the Colonial Office in London in the formulation of the Criminal Codes in the Central and East Africa (Okonkwo \& Nash, 2012).

An example of an English legislation which is effective in Nigeria by virtue of SOGA and which does not take into account Nigeria's peculiarity is the Wills Act 1837. The Act provides that a will "shall be revoked by the testator's marriage" unless the testator contemplates a marriage at the time the will is penned and the beneficiary is the partner in the contemplated marriage. In Nigeria, there are basically three types of marriage: Customary marriage, Islamic marriage and marriage under the Marriage Act (also known as statutory marriage or marriage under the Act). Marriage under the Act accommodates only monogamous marriage (see, for instance, Chukwuma v Chukwuma, 1996 \& Obiekwe v Obiekwe, 1963). Thus, the understanding that statutory marriage is "the voluntary union for life of one man and one woman to the exclusion of all others" (Hyde $v$ Hyde, 1866). Also, the Matrimonial Causes Act 2004, for the purpose of maintenance custody and settlements, provides that marriage includes purported marriage that is void but does not accommodate one which is entered into "according to Muslim rites or other customary law". Statutory marriage refers to a marriage celebrated in a Marriage Registry before a Registrar of Marriage or a marriage celebrated in a licensed place of worship by a recognised minister of the religious denomination of that licensed place of worship (Marriage Act 2004).

Many Nigerians who marry under the Marriage Act also marry under the customary law. This creates a challenge in Nigeria for Wills Act (1837). This is exemplified in the saga that surrounded the will of a Nigerian federal minister of finance in the first republic, Festus Okotie-Eboh. Okotie-Eboh died in January 1966 in the course of a failed military coup. According to the facts in Jadesimi $V$ Okotie-Eboh (1996), Festus Okotie-Eboh married Jadesimi in 1942 under the customary law. He made a Will in 1947. He took Jadesimi in 1961 to Marriage Registry and got married to her under the Marriage Act. It was contended by a party in the case that the 1961 marriage revoked the Will by virtue of the afore-cited section 18 of the Wills Act 1837. By the contention, the party intended to deprive Jadesimi of her testamentary gift. As seen in Jadesimi $v$ Okotie-Eboh, Wills Act 1837 is an example of a foreign law which drafters (via SOGA provisions) copied without taking into account Nigeria-specific circumstance and peculiarity. ${ }^{12}$

\footnotetext{
${ }^{12}$ In Jadesimi v Okotie-Eboh, the Nigerian Supreme Court innovatively circumvented the effect of section 18 of the Wills Act 1837 by reasoning that "that where the same parties undergo a form of marriage under Customary law and subsequently go through another marriage under the Marriage Act, the second marriage is clearly valid as a monogamous marriage. It is also plain that such second marriage under the Marriage Act, converts, without doubt, the Customary law marriage that was 'potentially polygamous' to a monogamous marriage, which, as stated by the court below, is the form of marriage contemplated under Section 18 of the Wills Act 1837".
} 
In the fourth category of entropic practices, some drafters couch draft bills in terms that are so general that they "negate any real possibility of effective implementation" (Seidman \& Seidman, 2007: p. 26). Seidman and Seidman (2007: p. 26) cited as an example an Indonesian law that devolved power to the provinces by simply listing the new duties of the provinces but provides "little or no details" with regard to which of the agencies of the provinces would undertake the new tasks. Also, there was no training for the personnel of the agencies which would implement the law, thus it took some years for the provincial government to start up (Seidman \& Seidman, 2007: p. 26). Many Nigerian laws are replete with provisions that "negate any real possibility of effective implementation". An example is the security role of the governors of the federating units (states) in Nigeria. The Nigerian constitution, which is federal in orientation, recognises the governor of a state as the "chief executive of that state" (Constitution of the Federal Republic of Nigeria 1999, s. 176).

The Constitution provides that "the Governor of a State or such Commissioner of the Government of the State as he may authorise in that behalf, may give to the Commissioner of Police of that State such lawful direction with respect to the maintenance and securing of public safety and public within the state as he may consider necessary, and the Commissioner of police shall comply with these directions or cause them to be complied with". Constitution of the Federal Republic of Nigeria 1999, s. 215 (4). This constitutional provision is completely ineffective for the following reasons. First, the Police Service Commission, which is responsible for the assignment of the role of Commissioner of Police for a State to an individual, appears practically under the control of the Federal Government of Nigeria. This is because the president may remove any member of the Commission if the president is satisfied that "it is not in the interest of the Commission or the interest of the public that the member should continue in Office" (The Police Service Commission (Establishment) Act, 2001). Therefore, the extent that a Commissioner of Police may heed the security instruction of the Governor of a State may be subject to the degree of the Commissioner of Police's "kowtow" to the president because of the weakness of the commissioner's security of tenure. Thus, the Governor of Ekiti State in Nigeria would lament that in spite of the assistance that the state government renders to the police in the state by way of provision of vehicles, guns and bullets, uniforms and housing, he [just like other State Governors] "have no control over the police" (Eme \& Anyadike, 2012; p. 280). In some states, the state governments carry the extra burden of building and rehabilitating police stations (Adefi \& Aladi, 2013: p. 2311).

Second, the same constitution that gave the state governors power to give lawful security directions to the Commissioners of Police in their states makes complying with the directions subject to the Commissioners requesting that "the matter be referred to the President [of Nigeria] or such minister of the Government of the Federation as may be authorised in that behalf by the President for 
his directions" (Constitution of the Federal Republic of Nigeria 1999, s. 215 (4)). Third, a Commissioner of Police exercising his role in a state as the commander of the police contingent in his state of jurisdiction is limited by section 215 (2) of the same constitution which provides that the entire Nigeria Police Force shall be under the command of an Inspector-General of Police and that any contingents of the Nigeria Police Force which are stationed in any State shall be under the command of the Commissioner of Police of that State "subject to the authority of the Inspector-General of Police". The Inspector General of Police is appointed by the president (Constitution of the Federal Republic of Nigeria 1999, s. 215 (1) (a)). It is thus clear from the above that the constitutional provision that empowers the governor of a state to give lawful direction to the Commissioner of Police is weakened by the same constitution in such a way that there is a negation of "any real possibility of effective implementation".

\subsubsection{Trial-and-Error Procedure}

With regard to trial-and-error approach, the drafter merely drafts-without much deep reflection on the nature and policy issues around an unwanted behaviour-with the mind-set that if the law fails to resolve the social problem targeted, the legislature will simply be advised "to try again by enacting new laws" (Seidman \& Seidman, 2007: p. 27). Drafters, however, less often adopt this pragmatic trial-and-error procedure (Seidman \& Seidman, 2007: p. 27). In reality, this approach is difficult to detect by outsiders to the law drafting process. Only the drafter knows his/her mind-set unless such a mind-set is manifested. Thus, the difficulty of ascertaining the prevalence of this approach in the Nigerian law making process.

Moreover, the trial-and-error approach is not completely bereft of any benefit. This appears to be the dominant and widely accepted approach in the third moment of the Law and Development movement. This is because the new developmental state is characterised by frequent experimentation, learning and re-learning (see the following: Ibe-Ojiludu, 2018: p. 161; Trubek, 2014: p. 17; Sherman, 2009: pp. 1268-1269). This essentially requires the legislature to evolve a new law when an old one fails. "This entails tailoring development and its tools to the emerging exigencies of their local environment" (Ibe-Ojiludu, 2018: p. 161). Thus, the trial-and-error approach may not be entirely negative contrary to the portrayal by Seidman and Seidman.

\subsection{Summary}

As indicated above in this section, Ann Seidman and Robert Seidman pointed out why laws fail. Laws fail when the institutionalist legislative theory is ignored, when laws are drafted by reliance on entropic practices or when law drafters adopt the trial-and-error procedure (2007: p, 29). This section has demonstrated how these factors enumerated by Seidman and Seidman are reflected in the failure of law in Nigeria. 


\section{Literature on Development in Nigeria and the Third Moment in Law and Development}

\subsection{The Absence of Law-Factor in Literature on Development in Nigeria}

Literature on development in Nigeria accord little or no value to law. Law is not viewed or considered as a factor in the categorisation of Nigeria as non-developed. Chinua Achebe laments the inability of Nigeria to attain development because billions that came to the country's treasure in the years 1972 to 1982 were stolen and squandered. According to him, this was a missed opportunity for the country to transform the lives of the poor and the needy and launch the country into "the middle rank of developed nations". For Achebe, Nigeria's developmental problem is summarily that of leadership: "The trouble with Nigeria is simply and squarely failure of leadership" (Achebe, 1983: pp. 2-3).

Another writer, who believes that there is a "substantial nexus between good governance and sustainable development", sees development as attainable only if leaders strictly adhere to transparency, rule of law, full respect of human rights, political empowerment of people irrespective of ethnicity and sex, etc. (Nwosu, 2017: pp. 119-128). By mentioning rule of law as an important ingredient of development, the writer appears very close to affirming a role for law. However, he fails to clearly and indisputably give a role to law in the process of engineering a rule of law that is procedurally or substantially effective. The rule of law cannot possibly evolve in any of its procedural and substantial facets unless initiated by law.

In section 2 above, it is highlighted how Mick Moore believes that underdevelopment in Africa (of which Nigeria is part of) was shaped and continues to be shaped to a large extent by the interaction between countries in the global north who are rich and those of the global south. For Moore, therefore, Africa's (and by extension Nigeria's) underdevelopment is a product of the above-mentioned interaction. Here, Moore makes no reference to any form of legal factor.

Bekeh Utietiang (2015: pp. 5, 19) has argued that colonialism was an exploitative mission-the economic relationship between Africa and the colonising powers was built upon the exploitation of the colonial peoples' natural and human resources; the colonies were viewed as important to the sustenance of the British economy. Their so-believed "civilising-them" mission never included development. The Colonial Development and Welfare Act of 1940 (an Act of the British Parliament) marked a major policy shift in colonial development policy; the alleviation of colonial poverty "became a major goal designed to inoculate Britain from the United States' critique of colonial rule” (Utietiang, 2015: p. 6). Thus, the above-mentioned 10-year development plan meant to span from 1946 was born. Specifically on 8 December 1945, Governor Richards wrote to the Secretary of State and informed him that he would place the plan before the Legislative Council on the 12th and 13th of December (Utietiang, 2015: p. 18).

According to Utietiang, the development plan failed for three reasons: 1) fi- 
nancial resources were lacking-the depression and Britain's emergence from the war meant that Britain lacked the resources for carrying out a "robust development in the colonies"; 2) the colonial state had some "ingrained racial biases"-Nigeria had to contribute a substantial amount of the capital with which the development would be financed, but Nigerians were not involved in the development process; in fact, few Nigerians who served in the Legislative Council as unofficial members and in the development committees never had a vote; $\mathrm{Ni}$ gerians' future was created and determined by the British and not by Nigerians 3 ) and some officials of the Colonial Office in London and the colonialists in Nigeria have divergent conceptions of development (thus there was "bureaucratic wrangling between Nigeria and London") - this generated meetings that were endless and correspondences that went back and forth (Utietiang, 2015: pp. 19-20).

Utietiang (2015: p. 20) concludes that the above reasons for the failure of the 10-year development plan meant to run from 1946 invite us to rethink the reason for today's failure of development in sub-Saharan Africa; rather than blame corruption and ineptitude of African leaders for the failure, the problem with development in Africa lies "in the poor development plans crafted by Western or Western inspired technocrats and experts". What Utietiang is saying, in other words, is that development remains elusive to sub-Saharan Africa (which includes Nigeria) because of the western origin of its development process. The problem with this reasoning is that Utietiang gives the impression that sub-Saharan Africa is bound to retain western influence in their development journey. A country can decide to free itself from such influence if it wants. Secondly, sub-Saharan Africa is no less a "victim" of the western influence than the "Asian Tigers" we spoke about earlier. Thirdly, it is still difficult to see how what happened in 1945, many years before many countries in the sub-Saharan Africa got their independence, is viewed by the author as responsible for African's underdevelopment while discounting concrete effect of war and corruption in marring development to some African countries. To conclude on Utietiang, it is important to point out that his analysis above did not mention or attribute Africa's underdevelopment challenge to law.

\subsection{Law in the Third Moment of Law and Development}

What the above examples of literature on development in Nigeria and most of the literature on development in Nigeria fail to factor in is that "law itself is part of development" (Trubek, 2016), an understanding that is very dominant in today's evolution of what scholars have described as the "third moment or epoch" (Farrar, 2020; Ibe-Ojiludu, 2018; Trubek, 2016: p. 1; Sherman, 2009; Baderin, 2010) in the genealogy of Law and Development Movement. According to David Trubek, prior to the third moment in law and development, law was seen as "a means to some other goal" like economic growth, social protection or individual liberty. This is especially true in the second moment of Law and Development. 
The "Washington Consensus" promotes the adoption of human rights as part of the path to development. Beginning from the second moment of the law and development movement, issues of human rights which were unheard-of in the classical developmentalism/classical developmental state, became part and parcel of new development strategy.

But today, the scope of Law and Development has widened to accommodate law not just as a "means to some other goal" but as "part of development" itself. (Trubek, 2016) If, as Amartya Sen would point out, development is the expansion of the real freedoms which people enjoy (Sen, 2001, p. 3$)^{13}$, then law is crucial to the realisation of development. This is because freedom is usually given effect through law. Thus, legal protection for human rights (which embrace economic and social rights) and constitutional values must form part of the agenda of Law and Development together with judicial reform and economic law (Trubek, 2016: p. 1). Consequently, Trubek would affirm that "the existence of the rule of law is a goal in itself, a necessary part of the process of empowerment and capability-enhancement that constitutes development".

\section{Summary and Conclusion}

Discussions in sections 2, 3, 4 and 5 above show that Law and Development is not correctly conceived in the Nigerian legal terrain. Existing theoretical underpinnings in Law and Development are not factored-in in the understanding and practice of development and/or law in Nigeria. Practitioners in both fields, however, can be excused because as highlighted in the introduction in Section 1 above, Law and Development is not taught in Nigeria. Thus as it were, what began or rather became popular in the 1960s and characterised as the "first 'moment' in Law and Development" (Trubek \& Santos, 2006: pp. 1-2; Trubek, 2016: p. 1) - there is even some scholarly reflection about the evolution of the fourth moment! (Vandenhole, 2019: p. 265; Vandenhole, 2018)—is yet to be birthed in Nigeria. Law and Development is "a study of the conscious use of the normative system called 'law' to help bring about...development" (Ocran, 1978: p. 17). Awareness about issues bordering on Law and Development and conscious decision to deploy them to the advantage of Nigeria are abstract theoretical enterprises that are better promoted in the academia. If Law and Development is promoted in university law faculties in Nigeria, a new vision of law will emerge. Such a promotion will translate into a new modus operandi in which lawyers graduating from such law faculties which are "saturated" with issues of Law and

\footnotetext{
${ }^{13}$ Amartya Sen, Development as Freedom (Oxford University Press 2001) 3. Amarty Sen argues that this expansion entails removing what he calls "the major sources of unfreedom", namely poverty, tyranny, poor economic opportunities, "systematic social deprivation, neglect of public facilities", intolerance or repressive states' overactivity. From the above, what Sen is saying is that development is a term for describing the expansion and the removal of barriers to freedom which people enjoy. The freedom could be political freedom. It could be freedom to make social choices. It could be freedom to make economic choices. Sen's novel conception of development as "a process of expanding the real freedoms that people enjoy" provides a basis for the human rights-based approach to development, an approach championed by many in the Law and Development discourse.
} 
Development would view law as having some developmental impact which they will then hopefully reflect in legal practice. This will be a departure from the "orthodox" mind-set which conceives law as possessing only an "order and justice" function.

\section{Conflicts of Interest}

The author declares no conflicts of interest regarding the publication of this paper.

\section{References}

...Truth of the Matter Is That Corruption Is Systemic in Nigeria-Osibanjo (2017, March 3). Vanguard.

Achebe, C. (1983). The Trouble with Nigeria (pp. 2-3). Heinemann.

Adefi, O. M., \& Aladi, A. J. (2013). Re-Awakening the State Police Controversy in Nigeria: Need for Rethink. International Journal of Asian Social Science, 3, 2307-2314.

Agu v Ikewibe 4 (1991). 4 SCNJ 56 at 78. In T. O Elias (Ed.), The Nature of African Customary Law (p. 212). University Press 1956.

Aku v Aneku (1991). 8 NWLR Pt 209, 280 [292] CA (Ndoma-Egba JCA).

Alfa v Arepo (1963). WNLR 95 [97] (Duffus J).

Amodu Tijani v The Secretary, Southern Nigeria (1921). JELR 59845 (Privy Council).

Anghie, A. (2007). The Evolution of International Law: Colonial and Post-Colonial Realities. Third World Quarterly, 27, 739-753. https://doi.org/10.1080/01436590600780011

Aust, V., Morais, A. I., \& Pinto, I. (2019). How Does Foreign Direct Investment Contribute to Sustainable Development Goals? Evidence from African Countries. Journal of Cleaner Production, 245, Article ID: 118823.

https://doi.org/10.1016/j.jclepro.2019.118823

https://www.sciencedirect.com/science/article/abs/pii/S0959652619336935

Baderin, M. (2010). Law and Development in Africa: Towards a New Approach (pp. 4, 19, 27-30, 36, 39-40). NIALS.

Brandt, W., \& Other Members of an Independent Commission (1986). North-South: A Programme for Survival (p. 23). Report of the Independent Commission on International Development Issues, MIT Press.

Brimah Balogun and Scottish Nigeria Mortgage and Trust Co. v. Saka Chief Oshodi (1933). Law Reports of Nigeria (Vol. 10, p. 36).

Cairns, H. (1941). The Theory of Legal Science (p. 22). University of North Carolina Press. As Quoted in Julius Stone, Social Dimensions of Law and Justice (Maitland 1966) 741.

Chukwuma v Chukwuma [1996] 1 NWLR (Pt 426) 543, at 563 (per Achike, JCA) and Obiekwe v Obiekwe (1963) ENLR 196.

Company and Allied Matters Act 2020. s. 834.

Constitution of the Federal Republic of Nigeria 1999, s. 215 (4).

Constitution of the Federal Republic of Nigeria 1999, s. 315 (3)-(4) (b)-(c).

Constitution of the Federal Republic of Nigeria 1999, s. 176 (2).

Eke v Okwaranyia (2001). 4 SCNJ 300.

Eme, O., \& Anyadike, N. (2012). Security Challenges and the Imperatives of State Police. 
Review of Public Administration and Management, 1, 203-218.

Evidence Act (2011). ss. 16 (1) and 18 (3).

Farrar, S. A. (2020). Introduction: Law and Development in the Islamic World. Law and Development Review, 13, 335-344. https://doi.org/10.1515/ldr-2020-0046

Hallward-Driemeier, M., \& Hasan, T. (2013). Empowering Women: Legal Opportunities in Africa (pp. 19 -36). Agence Francaise de Development and the World Bank.

Hyde v Hyde (1866). L. R. I \& D.

Ibe-Ojiludu, S. (2018). The Failure of Nigeria's Economic and Financial Crimes Commission (Establishment etc) Act 2004 as a Development Act. Law and Development Review, 11, 127-171.

Ibe-Ojiludu, S. (2019). Koskenniemi on Sovereignty and Global Governance. International Journal of Law, 5, 41-48. https://doi.org/10.1515/ldr-2017-0034

Ibietan, J., \& Ekhousuchi, O. (2013). Trends in Development Planning in Nigeria: 1962 to 2012. Journal of Sustainable Development in Africa, 15, 291-311.

Ikejiaku, B.-V. (2009). The Concept “Development” Revisited towards Understanding: In the Context of Sub-Saharan Africa. Journal of Politics and Law, 2, 31, 36-37. https://doi.org/10.5539/jpl.v2n1p31

International Bank for Reconstruction and Development/World Bank (2000). Can Africa Claim the 21st Century?

Interpretation Act, Cap 123, LFN (2004). s. 32.

Jadesimi v Okotie-Eboh(1996). 2 NWLR Part 429, 128.

Land Use Charge Law (2018). Rules Governing the Distribution of the Lagos State Land Use Charge (Emphasis Is Mine).

Larrocal, G.-T., Arevalo-Serrano, J., Duran Vilal, A. et al, (2017). Human Development Index (HDI) of the Maternal Country of Origin as a Predictor of Perinatal Outcomes-A Longitudinal Study Conducted in Spain. BMC Pregnancy and Childbirth, $17,1-2$.

Lawal v Younan (1961). 1 All N. L.R 245 (pp. 266-269).

Lee, Y.-S. (2017). General Theory of Law and Development. Cornell International Law Journal, 50, 415-472.

Malinovsky, A., \& Dobrotvorsky, P. (2021a). Dialectics of Philosophical Pillars of the Law and Development Doctrine. Wisdom: Philosophy of Law, 1, 138-146.

https://doi.org/10.24234/wisdom.v1i1.668

Marriage Act, Cap M6, LFN (2004). ss. 21 and 27.

Mojekwu v Mojekwu (1997). 7 NWLR Pt 512, 283 CA.

Moore, M. (2001). Political Underdevelopment: What Causes "Bad Governance". Public Management Review, 3, 385-418. https://doi.org/10.1080/14616670110050020

Newton, S. (2006). The Dialectics of Law and Development. In D. M. Trubek, \& A. Santos (Eds.), The New Law and Economic Development: A Critical Appraisal (pp. 174-202). Cambridge University Press. https://doi.org/10.1017/CBO9780511754425.005

Nwachukwu v Nnoremele (1957). II ERLR 50 (Mbanefo J).

Nwosu, I. J. D. (2017). Good Governance and Sustainable Development in Nigeria: A Contextual Analysis. Journal of Management, 14, 119-128.

Ocran, T. M. (1978). Law in Aid of Development: Issues in Legal Theory, Institution Building and Economic Development in Africa (pp. 15-18). Ghana Publishing Corporation. 
Odhiambo, P. (2007). Global Trade and Development: An African Perspective. In The Ignatian Family PreWorld Social Forum Seminar. https://www.sjweb.info/documents/sjs/docs/PO GlobalTradeandDevelopment.htm

Ogundipe, S. (2020, March 8). Alpha Beta Speaks on New Lagos Land Use Law. Premium Times.

https://www.premiumtimesng.com/news/top-news/261114-alpha-beta-speaks-new-lag os-land-use-law.html

Ohiaeri v Akabeze (1992). 2 SCNJ 76 and Agu v Ikewibe 4 (1991) 4 SCNJ 56.

Okonkwo, C. O. (2012). Okonkwo and Nash on Criminal Law in Nigeria (p. 5). Spectrum.

Oyewunmi v Ogunesan (1990). 3 NWLR Pt 137, 182 [207] SC (Obaseki JSC).

Raportoru, A. M. (2016). The Potential Role of Turkey toward a Regional Human Rights Arrangement in Asia. International Journal of Political Studies, 2, 23-30.

Reporters, S. (2018, September 7). Breaking: Tinubu's Alpah Beta Accussed of N10OBN "Money Laundering, Tax Evasion, Fraud”. Sahara Reporters.

http://saharareporters.com/2018/09/07/breaking-tinubu\%E2\%80\%99s-alpha-beta-accu sed-n100bn-\%E2\%80\%98money-laundering-tax-evasion-fraud\%E2\%80\%99

Seers, D. (1969). The Meaning of Development (pp. 2-3). Institute of Development Communication 44, Institute of Development Studies.

Seidman, A., \& Seidman, R. B. (2007). Law, Social Change, Development: The Fatal Race-Causes and Solutions. In A. Seidman, et al. (Eds.), Africa's Challenge: Using Law for Good Governance and Development (pp. 20, 29). Africa World.

Seidman, R. (1972). Law and Development: A General Model. Law \& Society Review, 6, 311-342. https://doi.org/10.2307/3052987

Sherman, C. (2009). Law and Development Today: The New Developmentalism. German Law Journal, 10, 1257-1273. https://doi.org/10.1017/S2071832200018125

Stone, J. (1966). Social Dimensions of Law and Justice (pp. 741-797). Maitland Publications.

Szirmai, A. (2005). Developing Countries and the Concept of Development. In A. Szirmai (Ed.), The Dynamics of Socio-Economic Development: An Introduction (p. 7). Cambridge University Press. https://doi.org/10.1017/CBO9780511817342

The Police Service Commission (Establishment) Act (2001). s. 4 (2).

Transparency International (2020). Corruption Perceptions Index 2019. https://www.transparency.org/en/cpi/2019/results/nga

Trubek, D. (2014). Law and Development: 40 Years after Scholars in Self Estrangement-A Preliminary Review (p. 17). University of Wisconsin Law School Legal Studies Research Paper Series No. 1255 (Wisconsin).

https://papers.ssrn.com/sol3/papers.cfm?abstract id=2435190 https://doi.org/10.2139/ssrn.2435190

Trubek, D. (2016). Law and Development: Forty Years after "Scholars in Self-Estrangement". University of Toronto Law Journal, 66, 301-329. https://doi.org/10.3138/UTLJ.3671

Trubek, D., \& Santos, A. (2006). Introduction: The Third Moment in Law and Development Theory and the Emergence of a New Critical Practice. In D. M. Trubeck, \& A. Santos (Eds.), The New Law and Economic Development: A Critical Appraisal (pp. 1-18). Cambridge University Press. https://doi.org/10.1017/CBO9780511754425.001

Twinning, W. (2009). General Jurisprudence: Understanding Law from a Global Perspective (p. 323). Cambridge University Press. https://doi.org/10.1017/CBO9780511807374 
United Nations General Assembly (UNGA) (1997). Agenda for Development, Resolution 51/240, UN Doc A/RES/51/240. Para 1.

Utietiang, B. (2015). Historicizing Development: Nigeria's 1945 Colonial Plan. The Journal of Pan African Studies, 8 , 5.

Vandenhole, W. (2018). Beyond a Fourth Moment in Law and Developkent: A Plea for Heterodoxy.

https://intr2dok.vifa-recht.de/servlets/MCRFileNodeServlet/mir derivate 00003584/V andenhole Beyond\%20a\%20fourth\%20moment.pdf https://doi.org/10.1515/ldr-2019-0013

Vandenhole, W. (2019). Towards a Fourth Moment in Law and Development. The Law and Development Review, 12, 265-283. https://doi.org/10.1017/9781108140348.002

Wills Act (1837). s. 18.

World Bank (1990). World Development Report 1990 (p. 26). World Bank.

Zaidan v Mohssen (1973). II SC 1[2] (Elias CJN). 